\title{
Murumuru (Astrocaryum murumuru) meal as an additive to elephant grass silage
}

\author{
Torta de murumuru (Astrocaryum murumuru) como aditivo en el ensilado de pasto elefante \\ Torta de murumuru (Astrocaryum murumuru) como aditivo em silagens de capim elefante
}

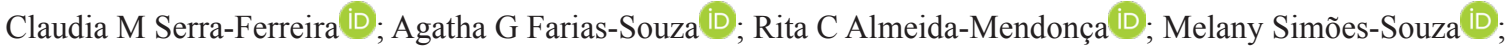
Wagner R L Lopes-Filho ${ }^{D}$; Cristian Faturi iD; Felipe Nogueira-Domingues (iD); Aníbal C do-Rêgo* (iD).
\end{abstract}

Study Group on Ruminants and Forage Production of the Amazon, Universidade Federal Rural da Amazônia.

To cite this article:

Murumuru meal as an additive to elephant grass silage. Serra-Ferreira CM, Farias-Souza AG, Almeida-Mendonça RC, SimõesSouza M, Lopes-Filho WRL, Faturi C, Nogueira-Domingues F, do-Rêgo AC. Rev Colomb Cienc Pecu 2020; 33(4): $264-272$. DOI: https://doi.org/10.17533/udea.rccp.v33n4a06

\begin{abstract}
Background: Tropical grasses, such as elephant grass, have high moisture content during its ideal phenological state for silage. High moisture content hinders proper preservation and reduces the nutritive value of silage due to secondary fermentation and production of effluents. Adding feed materials with high dry matter content, such as murumuru (Astrocaryum murumuru) meal, is a potential alternative to improve silage yield. Objective: To determine the effects of including murumuru meal $(0,7$, 14,21 , and $28 \%$ ) on the fermentative characteristics, microbiological activity, aerobic stability, and chemical composition of elephant grass silages. Methods: A completely randomized design with five treatments and five replicates was used. Elephant grass was collected at $60 \mathrm{~d}$ of age, minced, and homogenized with murumuru meal. The mass was placed in experimental 15-L silos. The silos were collected and analyzed $45 \mathrm{~d}$ later. Results: Effluent production decreased $(\mathrm{p}<0.05)$ as the proportions of murumuru meal in silage increased. A quadratic effect $(p<0.05)$ was observed on dry matter recovery. An increase $(p<0.05)$ was observed in dry matter content, a decrease $(p<0.05)$ in the neutral detergent fiber content, and an increase $(p<0.05)$ in the non-fibrous carbohydrate content with the inclusion of murumuru meal. Conclusions: Addition of murumuru meal improves chemical composition and does not affect the fermentative characteristics of elephant grass silage, while it reduces effluent losses. Nevertheless, the inclusion of murumuru meal in the elephant grass silage decreased the time of aerobic stability.
\end{abstract}

Keywords: additives; Astrocaryum murumuru; by-product; conservation; elephant grass; effluents; fermentation; forage;

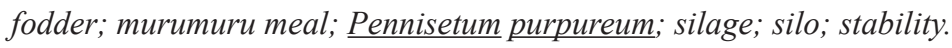

Received: March 11, 2020; accepted: May 29, 2020

*Corresponding author. Avenida Presidente Tancredo Neves, nº 2501, Belém, Pará, 66077-830, Brazil. E-mail: anibalcr@gmail.com 


\section{Resumen}

Antecedentes: los pastos tropicales, tales como el pasto elefante, tienen alto contenido de humedad cuando están en su estado fenológico ideal para ensilar. Esto dificulta su adecuada preservación en el silo, reduciendo el valor nutritivo del ensilaje debido a fermentaciones secundarias y generación de efluentes. Una posible solución sería incluir materiales con alto contenido de materia seca, tales como la torta de murumuru (Astrocaryum murumuru). Objetivo: determinar el efecto de la inclusión de torta de murumuru $(0 ; 7 ; 14 ; 21$ y 28\%) sobre las características fermentativas, microbiológicas, estabilidad aeróbica y composición química de los ensilajes de pasto elefante. Métodos: se utilizó un diseño completamente al azar, con cinco tratamientos y cinco repeticiones. El pasto elefante fue colectado a los 60 días de edad, luego picado y homogeneizado con la torta de murumuru. La masa fue colocada en silos experimentales con capacidad de 15 L. Luego de 45 días de ensilado, los silos fueron abiertos y las muestras fueron colectadas para su posterior análisis. $\operatorname{Resultados:~hubo~reducción~}(\mathrm{p}<0,05)$ en la producción de efluentes a medida que se incrementó la proporción de torta de murumuru en el ensilado. Se observó un efecto cuadrático $(\mathrm{p}<0,05)$ en la recuperación de materia seca. Hubo aumento $(\mathrm{p}<0,05)$ en los contenidos de materia seca con la adición de torta de murumuru. Se observó disminución $(\mathrm{p}<0,05)$ en el contenido de fibra detergente neutra y aumento $(\mathrm{p}<0,05)$ de carbohidratos no fibrosos. Conclusión: La adición de torta de murumuru mejora la composición química, reduce las perdidas por efluentes y no afecta las características fermentativas de ensilado de pasto elefante. Sin embargo, la inclusión de la torta de murumuru en el ensilado de pasto elefante disminuye el tiempo en estabilidad aeróbica.

Palabras clave: aditivos; Astrocaryum murumuru; conservación; efluentes; ensilaje; estabilidad; fermentación; forraje; harina de murumuru; pasto elefante; pienso; Pennisetum purpureum; silo; subproducto.

\section{Resumo}

Antecedentes: capins tropicais, como por exemplo o capim-elefante apresentam alto teor de umidade quando possuem produtividade compatível e estão no estádio fenológico adequado para ensilagem. Isso dificulta a adequada preservação no silo, ocasionando a redução do valor nutritivo da silagem devido a fermentações secundárias e a produção de efluentes. Uma possível solução seria o uso de aditivos com alto teor de matéria seca, como bolo de murumuru (Astrocaryum murumuru). Objetivo: determinar o efeito da inclusão da torta de murumuru $(0 ; 7 ; 14 ; 21$ e 28\%) na ensilagem de capim-elefante sobre as características fermentativas, microbiológicas, estabilidade aeróbia e a composição química das silagens. Métodos: utilizouse um delineamento inteiramente casualizado, com cinco tratamentos e cinco repetições. O capim-elefante foi colhido aos 60 dias de idade, o mesmo foi picado e homogeneizado à torta de murumuru. A massa foi ensilada em silos experimentais com capacidade de $15 \mathrm{~L}$. Após 45 dias de ensilagem, os silos foram abertos e amostras foram coletadas para posteriores análises laboratoriais. Resultados: houve redução $(\mathrm{p}<0,05)$ na produção de efluentes à medida que se elevaram as proporções da torta de murumuru na ensilagem. Observou-se efeito quadrático $(p<0,05)$ na recuperação de matéria seca. Houve aumento $(p<0,05)$ nos teores de matéria seca com a adição da torta murumuru. Observou-se diminuição $(\mathrm{p}<0,05)$ nos teores de fibra em detergente neutro e aumento $(\mathrm{p}<0,05)$ nos teores de carboidratos não fibrosos. Conclusão: torta de murumuru como aditivo melhora a composição química, reduz perdas principalmente por efluente e não afeta as características fermentativas de silagens de capimelefante. Entretanto, a inclusão da torta de murumuru na ensilagem de capim-elefante diminui o tempo em estabilidade aeróbia.

Palavras-chave: aditivos; Astrocarvum murumuru; capim-elefante; conservação; efluentes; ensilagem; estabilidade; fermentação; forragem; Pennisetum purpureum; silagem; silo; subproduto; torta de murumuru. 


\section{Introduction}

Effective preservation of tropical grass is a management strategy to ensure the availability of feed for animals throughout the year (Daniel et al., 2019). Tropical grass silage species are easy to manage, have high biomass production, and high nutritional value during the wet period (Tomaz et al., 2018). However, according to the same researchers, in this vegetative stage the grass has a high moisture content, which hinders its preservation in silage form and favors the growth of undesirable microorganisms (e. g., Clostridia), resulting in secondary fermentation and effluent production.

Among tropical grasses, elephant grass (Pennisetum purpureum Schum.) is one of the most widely used species in silage production because it is easy to handle and highly productive [approximately 80 tons of dry matter (DM)/ha/ year] (Rocha et al., 2017). However, similar to other tropical grass species, elephant grass has high moisture content $(75-82 \%)$ at the ideal cutting stage, thereby strategies are needed to improve the fermentative profile of the silage (Santos et al., 2013). Absorbent additives may be used to improve the fermentation process and reduce effluent losses in tropical grass silages. These additives act as moisture absorbing agents, increase the DM content of the ensiled material, produce minimal leachate, and indirectly inhibit the action of spoilage microorganisms (Daniel et al., 2019). Thus, additives can improve silage quality of tropical grasses (Rêgo et al., 2010).

The Amazon biome holds a high diversity of oilseeds that are used in agribusiness to produce cosmetics, fuels, food, and other products (Funasaki et al., 2016). Among these, murumuru (Astrocaryum murumuru) stands out as a promising species for oil extraction, which generates a byproduct during this process (Mota et al., 2015). Usually, such byproduct has a high DM $(>85 \%)$ and satisfactory chemical composition, making it suitable for inclusion in ruminant diets (Menezes et al., 2016).
The objective of this study was to determine the effects of including increasing concentrations of murumuru meal on the fermentative characteristics, microbiological activity, aerobic stability, and chemical composition of elephant grass silage.

\section{Materials and methods}

Elephant grass was grown in a grassland area, located at $1^{\circ} 27^{\prime} 07^{\prime \prime} \mathrm{S}, 48^{\circ} 26^{\prime} 14^{\prime \prime} \mathrm{W}$, at an altitude of approximately $15 \mathrm{~m}$. The climate of the region, according to the Köppen-Geiger classification, is Af type. The grass was harvested manually near ground level at $60 \mathrm{~d}$ of growth and then processed in a forage chopper to obtain $1.0 \mathrm{~cm}$ theoretical particle size (Nogueira, Itapira, São Paulo, Brazil). The material was ensiled in $15 \mathrm{~L}$ plastic buckets, with sand and non-woven fabric (TNT) on the bottom to quantify effluent production. An average of $15 \pm 2 \mathrm{~kg}$ of forage or forage natural matter (NM) was ensiled in each silo, at $600 \mathrm{~kg} / \mathrm{m}^{3}$ density.

Murumuru meal was sourced from a local company in Ananindeua, Pará (Brazil). The meal is the byproduct of mechanical extraction of oil from murumuru seeds. Before ensiling, elephant grass and murumuru meal samples were collected for chemical characterization (Table 1). Several murumuru meal concentrations $[0.0,7.0,14.0,21.0$, and $28.0 \%$, depending on the $\mathrm{NM}$ of the ensiled mass] included in elephant grass ensiling were evaluated.

After processing, elephant grass and murumuru meal were weighed, homogenized, and compacted in the silos. Subsequently, the silos were sealed and weighed. After 93 $\mathrm{d}$, the silos were re-weighed to quantify dry matter recovery (DMR; Jobim et al., 2007). Then, the silos were opened and weighed. The visually deteriorated portion was weighted (WDM). Then, the sand and TNT were considered to determine the effluent losses (EL), and silage losses were estimated using equations proposed by Jobim et al. (2007), disregarding the deteriorated silage portion 
from the total weight of the silo after opening. An $800 \mathrm{~g}$ sample was taken from each silo, part of which was used for microbiological evaluation; the remaining sample was packed in plastic bags and stored at $-20{ }^{\circ} \mathrm{C}$ for further chemical composition analysis and evaluation of fermentative characteristics.

The microbiological evaluation was performed using an aqueous extract composed of $25 \mathrm{~g}$ of silage and $225 \mathrm{~mL}$ of peptone water $(1 \mathrm{~g} / \mathrm{L}$ of water), which was manually homogenized for $3 \mathrm{~min}$ in closed sterile bags. The extract was surface-plated on potato dextrose-agar (SigmaAldrich, Ribeirão Preto, São Paulo, Brazil). Yeast and mold colonies were counted after incubation at $26^{\circ} \mathrm{C}$ for 2 and $5 \mathrm{~d}$, respectively. The $\mathrm{pH}$ of the aqueous extract was measured at time zero using a potentiometer (Tekna, São Bernardo do Campo, São Paulo, Brazil). Ammonia nitrogen $\left(\mathrm{N}-\mathrm{NH}_{3}\right)$ analysis was performed according to method No. 941.04 (AOAC, 1990).

For the organic acids (lactic, acetic, propionic, butyric, isobutyric, valeric, and isovaleric acids) evaluation, $25 \mathrm{~g}$ samples were weighed, solubilized in $300 \mathrm{~mL}$ of deionized water, and processed in a stomacher-type homogenizer (Cole-Parmer, Madison, Wisconsin, USA). Subsequently, $1 \mathrm{~mL}$ of the supernatant liquid was removed for gas chromatography. An Agilent 7890A gas chromatograph equipped with a flame ionization detector (7683B) and a fused silica capillary column (J \& W 19091F-112; Agilent Technologies, Santa Clara, CA, USA) was used. After that, total organic acids were determined summing all evaluated acids. The lactic acid and acetic acid ratio (LA:AA) was established by dividing lactic acid by acetic acid contents.

For evaluating aerobic stability after opening the silos, $500 \mathrm{~g}$ of silage was placed in 25 plastic buckets $(9 \mathrm{~L})$, which were covered with aluminum foil to prevent loss of silage moisture. The buckets and silages were kept in an air-conditioned room at $20{ }^{\circ} \mathrm{C}$ for $12 \mathrm{~d}$, where ambient and silage temperatures were recorded every $30 \mathrm{~min}$ using data loggers (Escort, Buchanan, Virgínia, USA). Aerobic stability was defined as the number of hours the silage remained stable before reaching $2{ }^{\circ} \mathrm{C}$ above room temperature.

The samples were pre-dried in a forced-air circulation oven at $55^{\circ} \mathrm{C}$ for $72 \mathrm{~h}$ and then ground in a mill fitted with a $1 \mathrm{~mm}$ sieve. The DM, ash, ether extract (EE), and crude protein (CP) content was determined according to the AOAC (1990) methodology (methods No. 934.01, No. 923.03, No. 920.39, and No. 978.04, respectively). The methods by Van Soest and Robertson (1985) were used to analyze neutral detergent fiber (NDF), acid detergent fiber (ADF), and acid detergent lignin (ADI) levels, which were determined by solubilization of cellulose with sulfuric acid. Non-fiber carbohydrates were quantified according to the method by Detmann and Valadares Filho (2010). For the determination of total soluble, the methodology described by Dubois et al. (1956) was used.

\section{Statistical analysis}

A completely randomized experimental design with five replicates per concentration was used. Before statistical analysis, the molds count data were $\log _{10}$-transformed. The fermentation, microbiological characteristics, aerobic stability, and chemical composition data of elephant grass silage was submitted to analysis of variance and polynomial and simple linear regression analysis to study the effects of murumuru meal concentrations. For this, we used the SAS $^{\circledR}$ Statistical Analysis Program, Version 6 (Statistical Analysis System, 2001), with $5 \%$ as the significance level.

The mathematical model was as follows: Yij $=\mu+\mathrm{Ti}+$ eij. Where: Yij $=$ observation $\mathrm{j}$, referring to each inclusion level of murumuru meal (i); $\mu=$ overall average; Tij = effect of the inclusion level of murumuru meal; and eij = error associated with each observation.

\section{Results}

Chemical composition of elephant grass fresh and murumuru meal are presented in Table 1. 
Table 1. Chemical composition of fresh elephant grass and murumuru meal.

\begin{tabular}{ccc}
\hline Item (\% DM) & Elephant grass & Murumuru meal \\
\hline DM \% FM & 17.8 & 89.7 \\
OM & 95.3 & 97.4 \\
Ash & 4.7 & 2.7 \\
CP & 10.6 & 8.8 \\
EE & 1.8 & 15.1 \\
NDF & 72.5 & 37.9 \\
ADF & 40.2 & 26.1 \\
HEM & 32.3 & 11.8 \\
CEL & 36.5 & 12.4 \\
LIG & 3.7 & 13.7 \\
NFC & 10.4 & 35.5 \\
SC & 2.7 & 10.5 \\
\hline
\end{tabular}

$\mathrm{DM}=$ dry matter, $\mathrm{FM}=$ fresh matter, $\mathrm{OM}=$ organic matter, $\mathrm{CP}$ $=$ crude protein, $\mathrm{EE}=$ ether extract, $\mathrm{NDF}=$ neutral detergent fiber, $\mathrm{ADF}=$ acid detergent fiber, HEM $=$ hemicellulose, $\mathrm{CEL}$ $=$ cellulose, $\mathrm{LIG}=$ lignin, $\mathrm{NFC}=$ non-fibrous carbohydrate, and $\mathrm{SC}=$ soluble carbohydrates.
There was a reduction $(\mathrm{p}<0.05)$ in the effluent production of elephant grass silage with the inclusion of murumuru meal (Table 2). With the inclusion of murumuru meal, a quadratic effect $(p<0.05)$ on the dry matter recovery of silages $(\mathrm{DMR} \%)$ was observed along with an increase $(p<0.05)$ in the portion of deteriorated material in the silages that included the additive. An increase $(p<0.05)$ in mold count was noted with the inclusion of murumuru meal to elephant grass silage. Yeast was not detected $(p>0.05)$ in the silage, that is, the count was below $2.0 \mathrm{cfu}$ $\mathrm{g}^{-1}$ of forage.

A quadratic effect $(p<0.05)$ was observed in the $\mathrm{pH}$ value with the inclusion of murumuru meal in elephant grass silage (Table 3 ). Ammonia nitrogen $\left(\mathrm{N}-\mathrm{NH}_{3}\right)$ content of silages increased linearly $(p<0.05)$ with the inclusion of murumuru meal. There was no effect ( $p>0.05)$ of the additive on the lactic acid concentration of the silages.

Table 2. Fermentative losses and microbial composition of elephant grass silage containing murumuru meal.

\begin{tabular}{|c|c|c|c|c|c|c|c|}
\hline \multirow{2}{*}{ Item } & \multicolumn{5}{|c|}{ Inclusion of murumuru meal (\%) } & \multirow{2}{*}{ Regression equation } & \multirow{2}{*}{$\mathbf{R}^{2}$} \\
\hline & 0 & 7 & 14 & 21 & 28 & & \\
\hline Effluents (kg/ton NM) & 72.4 & 9.2 & 1.3 & 1.3 & 1.2 & $\mathrm{Y}=65.54-15.71 \mathrm{x}$ & 0.62 \\
\hline $\operatorname{DMR}(\%)$ & 95.8 & 84.8 & 82.3 & 85.3 & 84.1 & $Y=94.65-1.35 X+0.04 x^{2}$ & 0.85 \\
\hline $\operatorname{PDM}(\mathrm{g})$ & 408 & 875 & 1280 & 1098 & 1129 & $Y=450.50+170.50 x$ & 0.43 \\
\hline Molds $\left(\log 10 \mathrm{cfu} \mathrm{g}^{-1}\right)$ & 2.63 & 2.83 & 2.78 & 3.22 & 3.58 & $\mathrm{Y}=2.30+0.23 \mathrm{x}$ & 0.62 \\
\hline
\end{tabular}

$\mathrm{NM}=$ Natural matter; DMR $=$ Dry matter recovery; PDM = Portion of deteriorated material.

Table 3. Fermentative characteristics and aerobic stability of elephant grass silages containing murumuru meal.

\begin{tabular}{|c|c|c|c|c|c|c|c|}
\hline \multirow{2}{*}{ Item } & \multicolumn{5}{|c|}{ Inclusion of murumuru meal (\%) } & \multirow{2}{*}{ Regression equation } & \multirow{2}{*}{$\mathbf{R}^{2}$} \\
\hline & $\mathbf{0}$ & 7 & 14 & 21 & 28 & & \\
\hline $\mathrm{pH}$ & 3.50 & 3.30 & 3.30 & 3.40 & 3.48 & $Y=3.47-0.026 x+0.01 x^{2}$ & 0.85 \\
\hline $\mathrm{N}-\mathrm{NH}_{3}(\% \mathrm{~N}$ total $)$ & 2.94 & 3.15 & 3.35 & 3.88 & 4.09 & $\mathrm{Y}=2.87+0.04 \mathrm{x}$ & 0.77 \\
\hline Lactic acid (\%DM) & 1.57 & 1.75 & 2.55 & 1.70 & 1.60 & $\mathrm{Y}=1.83$ & - \\
\hline Acetic acid $(\% \mathrm{DM})$ & 2.80 & 1.80 & 0.80 & 0.50 & 1.10 & $Y=2.34-0.07 x$ & 0.45 \\
\hline $\mathrm{LA}: \mathrm{AA}(\% \mathrm{DM})$ & 0.56 & 0.97 & 3.19 & 3.4 & 1.45 & $Y=1.86-0.16 x+0.004 x^{2}$ & 0.44 \\
\hline OA-total (\%DM) & 4.37 & 3.55 & 3.35 & 2.20 & 2.70 & $Y=4.38-0.13 x+0.002 x^{2}$ & 0.37 \\
\hline $\mathrm{AE}$ & 147.4 & 122.8 & 120.6 & 97.8 & 110. & $Y=140.1-148 x$ & 0.22 \\
\hline
\end{tabular}

${\mathrm{N}-\mathrm{NH}_{3}}_{3} \mathrm{NT}=$ ammonia nitrogen $(\%$ total nitrogen $) ; \mathrm{DM}=$ Dry matter; OA-total = Total organic acids; AE = aerobic stability; LA:AA $=$ lactic acid/acetic acid. 
However, there was a linear decrease $(\mathrm{p}<0.05)$ in the acetic acid content of silages with the inclusion of murumuru meal. A quadratic effect $(p<0.05)$ was observed in the LA:AA ratio and the total organic acid concentration with the inclusion of murumuru meal in the elephant grass silage. Butyric, propionic, isobutyric, valeric, and isovaleric acids were not present in the silages. There was a linear reduction $(p<0.05)$ in the aerobic stability of silages with the inclusion of murumuru meal.

The addition of murumuru meal in elephant grass silage linearly increased $(\mathrm{p}<0.05)$ the DM content of the silage (Table 4). However, it did not change $(\mathrm{p}>0.05)$ the $\mathrm{OM}$ or ash content of the silages. There was a reduction $(p<0.05)$ in the $\mathrm{CP}$ content of silages with the inclusion of murumuru meal, while a quadratic effect $(p<0.05)$ was noted on the EE levels.

A linear $(p<0.05)$ reduction in the NDF content of elephant grass silages was observed with the inclusion of murumuru meal. Regarding the ADF, cellulose, and lignin levels, a quadratic effect $(p<0.05)$ was observed with the inclusion of the additive. The hemicellulose content decreased linearly $(p<0.05)$, and the NFC levels increased $(p<0.05)$ with the inclusion of the additive to the silage.

Table 4. Chemical composition of elephant grass silage with the addition of murumuru meal.

\begin{tabular}{lcccccccc}
\hline \multirow{2}{*}{ Item } & \multicolumn{6}{c}{ Inclusion of murumuru meal (\%) } & \multirow{2}{*}{ Regression equation } & \multirow{2}{*}{$\mathbf{R}^{\mathbf{2}}$} \\
\cline { 2 - 6 } & $\mathbf{0}$ & $\mathbf{7}$ & $\mathbf{1 4}$ & $\mathbf{2 1}$ & $\mathbf{2 8}$ & & \\
\hline DM & 18.06 & 21.62 & 26.39 & 31.62 & 36.08 & $\mathrm{Y}=17.549+0.658 \mathrm{x}$ & 0.98 \\
OM & 95.41 & 95.36 & 95.99 & 95.53 & 95.66 & 95.57 & - \\
Ash & 4.59 & 4.63 & 4.00 & 4.47 & 4.34 & 4.42 & - \\
CP & 10.68 & 10.40 & 10.23 & 9.83 & 9.78 & $\mathrm{Y}=10.660-0.034 \mathrm{x}$ & 0.57 \\
EE & 1.96 & 3.42 & 5.08 & 5.74 & 5.68 & $\mathrm{Y}=1.775+0.336 \mathrm{x}-0.007 \mathrm{x}^{2}$ & 0.71 \\
NDF & 65.28 & 57.10 & 53.90 & 47.98 & 45.82 & $\mathrm{Y}=63.620-0.686 \mathrm{x}$ & 0.85 \\
ADF & 40.03 & 36.07 & 33.33 & 29.08 & 29.81 & $\mathrm{Y}=40.271-0.712 \mathrm{x}+0.011 \mathrm{x}^{2}$ & 0.79 \\
HEM & 25.25 & 21.02 & 20.57 & 18.90 & 16.02 & $\mathrm{Y}=24.468-0.294 \mathrm{x}$ & 0.71 \\
CEL & 32.81 & 25.82 & 21.58 & 17.38 & 19.14 & $\mathrm{Y}=33.010-1.227 \mathrm{x}+0.025 \mathrm{x}^{2}$ & 0.77 \\
LIG & 7.22 & 10.25 & 11.75 & 11.70 & 10.67 & $\mathrm{Y}=7.263+0.514 \mathrm{x}-0.014 \mathrm{x}^{2}$ & 0.52 \\
NFC & 18.64 & 26.22 & 29.33 & 34.01 & 36.52 & $\mathrm{Y}=20.230+0.622 \mathrm{x}$ & 0.76 \\
\hline
\end{tabular}

$\mathrm{DM}=$ dry matter, $\mathrm{OM}=$ organic matter, $\mathrm{CP}=$ crude protein, $\mathrm{EE}=$ ether extract, $\mathrm{NDF}=$ neutral detergent insoluble fiber, $\mathrm{ADF}=$ acid detergent fiber, $\mathrm{HEM}=$ hemicellulose, $\mathrm{CEL}=$ cellulose, $\mathrm{LIG}=$ lignin, $\mathrm{NFC}=$ non-fibrous carbohydrate.

\section{Discussion}

Absorbent additives can increase DM content of the silage ( $>85 \%$ ), allowing them to act as moisture scavengers and increase the DM content of the ensiled material, reducing EL in high humidity silages (Razak et al., 2012). The murumuru meal used in this study had DM content above the minimum values suggested for a moisture sequestering additive. This characteristic allowed it to decrease effluent production in the grass silage (Table 2). This reduction has a direct effect on reducing the potential environmental impact of the effluent. Silage effluent is a pollutant that can cause eutrophication of water bodies (Gebrehanna et al., 2014).

The increase in PDM with the inclusion of murumuru meal was probably a reflection of the rise on NFC content on these silages. It is possible that the chemical composition of murumuru meal in elephant grass ensiling provided a greater input for the proliferation of undesirablemicroorganisms, which deteriorated the ensiled mass (Monteiro et al., 2011). 
This was confirmed by the high mold count due to the inclusion of the additive. The fact that no yeast was observed in the silages does not necessarily mean that there was no presence of this group of microorganisms. Yeast may have been present in the culture medium used; however, the latter may not have been ideal for cultivating such microorganisms. The presence of mold in the silages may be associated with the deleterious effects of oxygen, especially in the upper portion of the silo due to the difficulty of compacting this region during ensiling (Borreani et al., 2018), reflecting the high PDM levels. This result contributed to the low DMR levels in murumuru meal silages.

Although there was an increase in the $\mathrm{N}-\mathrm{NH}_{3}$ content with murumuru meal inclusion, the highest content observed was still below the range considered desirable $(<12 \%)$ for quality silage (Lopes and Evangelista, 2010). However, our results showed that the proteolysis that occurred during fermentation was not enough to alter CP levels, which varied below the $1.5 \%$ level among silages. That indicates no excessive protein degradation at the levels studied.

Lactic acid content observed in the silages indicate that fermentation occurred adequately as it was mainly responsible for the reduction in $\mathrm{pH}$ during ensiling and for maintaining acidification of the mass until the silo was opened. This response was evidenced by the $\mathrm{pH}$ values observed at this time, as well as by their similarity irrespective of murumuru meal inclusion. Reduction in acetic acid concentration with the addition of murumuru meal was probably a limiting factor in inhibiting mold growth in elephant grass as this acid has antifungal properties. The LA:AA ratio and total organic acid concentration reflected the aforementioned acid concentrations.

Reduction of aerobic stability of the silages with inclusion of murumuru meal occurred due to increase in NFC with meal addition (Table 4). The NFC are substrates used by spoilage microorganisms in the silage. The high substrate input evidenced by NFC content, high mold count, and low acetic acid concentration results in less stable silages when the additives are included (McDonald et al., 1991).

Increase in DM content of the silage with inclusion of murumuru meal was caused by high DM content of the additive, thus, demonstrating its potential as an absorbent additive for grass silage. The similarity in $\mathrm{OM}$ and ash concentrations among silages was probably caused by the similarity of these constituents in the meal and elephant grass.

Reduction in NDF, ADF, HEM, and CEL content with inclusion of murumuru meal in grass silage was probably caused by the lower content of these components in murumuru meal than in elephant grass. By adding murumuru meal to elephant grass silage, the concentrations of these components decreased proportionally. Despite reduction of NDF, ADF, HCEL, and CEL parameters in elephant grass silage with the inclusion of murumuru meal, lignin content increased. Lignin is a component that can interfere with feed digestibility. Its increase was anticipated as murumuru meal has higher lignin content $(13.7 \%)$ than that of elephant grass (3.7\%). High lignin levels may compromise the use of food by ruminal microorganisms and affect DM digestibility as they make part of unavailable cell wall components, thus resulting in fiber degradation (Wilson and Hatfield, 1997).

Increase in the NFC content of the silages with inclusion of murumuru meal was probably caused by high NFC content in the meal. Non-fibrous carbohydrates are considered mostly soluble and highly digestible, thereby increasing the nutritional value of the feed. In the case of silages, this increase in nutritional value depends on the microorganisms (homofermentative or heterofermentative), and products such as water, heat, carbon dioxide, lactic acid, alcohol, and volatile fatty acid generated (Muck, 2010). 
In conclusion, including up to $28 \%$ murumuru meal in elephant grass silage improves the chemical composition of the silage, but it makes it more susceptible to deterioration when exposed to oxygen. Based on these results, we recommend to offer elephant grass-murumuru meal silage to the animals shortly after it is removed from the silo to avoid significant losses from aerobic deterioration.

\section{Declarations}

\section{Acknowledgments}

The authors thank the undergraduate and graduate students from the Grupo de Estudos em Ruminantes e Forragicultura da Amazônia (GERFAM) for their technical support.

\section{Funding}

This study was partly funded by the Coordenação de Aperfeiçoamento de Pessoal de Nível Superior - Brasil (CAPES) - Finance Code 001 (PROCAD 071/2013).

\section{Conflicts of interest}

The authors declare they have no conflicts of interest with regard to the work presented in this report.

\section{Author contributions}

Claudia M Serra-Ferreira and Agatha $\mathrm{G}$ Farias-Souza participated of the formal analysis and writing-original draft. Rita C Almeida-Mendonça and Wagner R L LopesFilho were responsible for methodology and investigation. Melany Simões-Souza wrote, revised and edited the text. Cristian Faturi were responsible for statistical analyses. Felipe Nogueira-Domingues was supervisor. Aníbal $\mathrm{C}$ do-Rêgo participated in supervision and administration of the project.

\section{References}

BAOAC, 1990. Official Methods of Analysis. Association of Official Analytical Chemists, The Association: Arlington, VA, USA, 15th ed., p. 770.

Borreani G, Tabacco E, Schmidt RJ, Holmes BJ, Muck RE. Silage review: Factors affecting dry matter and quality losses in silages. J Dairy Sci 2018; 101(5):3952-3979. DOI: https://doi.org/10.3168/jds.2017-13837

Daniel JLP, Bernardes TF, Jobim CC, Schmidt P, Nussio LG. Production and utilization of silages in tropical areas with focus on Brazil. Grass Forage Sci 2019; 74(2):1-13. DOI: https://doi.org/10.1111/gfs.12417

Detmann E, Valadares Filho SC. On the estimation of non-fibrous carbohydrates in feeds and diets. Arq Bras Med Vet Zootec 2010; 62(4):980-984. DOI: http://dx.doi.org/10.1590/S0102 $\underline{09352010000400030}$

Dubois M, Gilles KA, Hamilton JK, Rebers PA, Smith F. Colorimetric methods for determination of sugars and substances. Analytical Chemistry 1956; 28(3):350-356.

Funasaki M, Barroso HS, Fernandes VLA, Menezes IS. Amazon rainforest cosmetics: chemical approach for quality control. Química Nova 2016; 39(2):194-209. DOI: http://dx.doi.org/10.5935/0100-4042.20160008

Gebrehanna MM, Gordon RJ, Madani A, VanderZaag AC, Wood JD. Silage effluent management: A review. J Environ Manage 2014; 143(1):113-122. DOI: https://doi.org/10.1016/j.jenvman.2014.04.012

Jobim CC, Nussio LG, Reis RA, Schimidt P. Avanços metodológicos na avaliação da qualidade da forragem conservada. R Bras Zootec 2007; 36 (Suppl):101-119. DOI: https://dx.doi.org/10.1590/S1516$\underline{35982007001000013}$

Lopes J, Evangelista AR. Características bromatológicas, fermentativas e população de leveduras de silagens de cana-de-açúcar acrescida 
de ureia e aditivos absorventes de umidade. $\mathrm{R}$ Bras Zootec 2010; 39(5):984-991. DOI: https://doi.org/10.1590/S1516$\underline{35982010000500007}$

Mcdonald P, Henderson AR, Heron SJE. The biochemistry of silage. 2nd ed. Marlow (UK): Chalcombe Publications;1991. DOI: https://doi.org/10.1017/S0014479700023115

Menezes BP, Rodrigues LS, Lourenço Júnior JB, Silva AGM, Andrade SJT, Silva JAR, Faturi C, Garcia AR, Nahúm BS, Barbosa AVC, Budel JCC, Araújo GS. Intake, digestibility, and nitrogen balance of rations containing different levels of murumuru meal in sheep diets. Semina Ciênc Agrár 2016; 37(1):415-427. DOI: https://doi.org/10.5433/1679$\underline{0359.2016 \mathrm{v} 37 \mathrm{n} 1 \mathrm{p} 415}$

Monteiro IJG, Abreu JG, Cabral LS, Ribeiro MD, Reis RHP. Silagem de capim-elefante aditivada com produtos alternativos. Acta Sci Anim Sci 2011; 33(4):347-352. DOI: https://doi.org/10.4025/ actascianimsci.v33i4.12629

Mota PES, Moura RL, Portela GLF, Carvalho WF, Oliveira MRA. Perdas e características fermentativas da silagem de capim-elefante com diferentes aditivos. ACSA 2015; 11(1):126130. DOI: https://dx.doi.org/10.30969/acsa. v11i1.540

Muck RE. Silage microbiology and its control through additives. R Bras de Zootec 2010; 39 (Suppl):183-191. DOI: https://dx.doi. org/10.1590/S1516-35982010001300021

Razak AO, Masaaki H, Yimamu A, Meiji O. Potential water Retention capacity as a factor in silage effluent control: Experiments with high moisture by-product feedstuffs. AsianAustralasian. J Anim Sci 2012; 25(4):471-478. DOI: https://doi.org/10.5713/ajas. 2011-11349
Rêgo MMT, Neiva JNM, Rêgo AC, Cândido MJD, Clementino RH, Restle J. Nutritional evaluation of elephant-grass silages with byproduct of annatto. R Bras Zootec 2010; 39(10):2281-2287. DOI: https://doi.org/10.1590/S1516-35982010001000026

RochaJRASC,MachadoJC,CarneiroPCS,Carneiro JC, Resende MDV, Pereira AV, Carneiro JES. Elephant grass ecotypes for bioenergy production via direct combustion of biomass. Industrial Crops and Products 2017; 95(1):27-32. DOI: https://doi.org/10.1016/j.indcrop.2016.10.014

SantosRJC,LiraMA,Guim,A,SantosMVF,Dubeux Junior JCB, Mello ACL. Elephant grass clones for silage production. SciAgric 2013; 70(1):6-11. DOI: https://doi.org/10.1590/s0103$\underline{90162013000100002}$

Statistical Analysis System Institute Inc. SAS Language Reference. Version 6. Cary, NC, USA: SAS Institute, 2001. 1042 p.

Van soest PJ, Robertson JB. Analysis of forage and fibrous foods. Ithaca: Cornell University 1985; p.202.

Tomaz PK, Araujo LC, Sanches LA, Araujo SNS, Lima TO, Lino AA, Ferreira EM. Effect of sward height on the fermentability coefficient and chemical composition of Guinea grass silage. Grass Forage Sci 2018; 73(3):588-598. DOI: https://doi.org/10.1111/gfs.12349

Van soest PJ. Nutritional ecology of the ruminant. 2nd ed. (NY): Cornell University Press 1994; p.476.

Wilson JR, Hatfield RD. Structural and chemical changes of cell wall types during stem development: consequences for fibre degradation by rumen microflora. Australian J. Agric. Res 1997; 48(2):165-180. DOI: https://doi.org/10.1071/A96051 